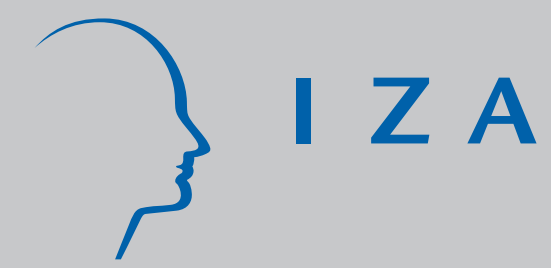

IZA DP No. 8636

Do Market Incentives in the Hospital Industry Affect Subjective Health Perceptions?

Evidence from the Italian PPS-DRG Reform

Lorenzo Cappellari

Anna De Paoli

Gilberto Turati

November 2014 


\title{
Do Market Incentives in the Hospital Industry Affect Subjective Health Perceptions? Evidence from the Italian PPS-DRG Reform
}

\author{
Lorenzo Cappellari \\ Catholic University Milano \\ and IZA
}

Anna De Paoli

University of Milano Bicocca

\section{Gilberto Turati}

University of Torino

\section{Discussion Paper No. 8636 \\ November 2014}

\author{
IZA \\ P.O. Box 7240 \\ 53072 Bonn \\ Germany \\ Phone: +49-228-3894-0 \\ Fax: +49-228-3894-180 \\ E-mail: iza@iza.org
}

Any opinions expressed here are those of the author(s) and not those of IZA. Research published in this series may include views on policy, but the institute itself takes no institutional policy positions. The IZA research network is committed to the IZA Guiding Principles of Research Integrity.

The Institute for the Study of Labor (IZA) in Bonn is a local and virtual international research center and a place of communication between science, politics and business. IZA is an independent nonprofit organization supported by Deutsche Post Foundation. The center is associated with the University of Bonn and offers a stimulating research environment through its international network, workshops and conferences, data service, project support, research visits and doctoral program. IZA engages in (i) original and internationally competitive research in all fields of labor economics, (ii) development of policy concepts, and (iii) dissemination of research results and concepts to the interested public.

IZA Discussion Papers often represent preliminary work and are circulated to encourage discussion. Citation of such a paper should account for its provisional character. A revised version may be available directly from the author. 
IZA Discussion Paper No. 8636

November 2014

\section{ABSTRACT}

\section{Do Market Incentives in the Hospital Industry Affect Subjective Health Perceptions? Evidence from the Italian PPS-DRG Reform*}

We exploit time variation across Italian Regions in the implementation of a prospective pay systems (PPS) for hospitals based on Diagnosis Related Groups (DRGs) to assess their impact on self-assessed health status and on the use of health care services. We consider a survey of more than 600,000 individuals, over the years 1993-2007, with information on both individuals' perceived health and their access to a number of health services. Results suggest that the introduction of market incentives via a fixed-price payment system does not lead to worst health perceptions. Instead, the reform marked a moderate decrease in hospitalization and day hospital treatments, coupled with a clear decrease in the access to emergency services. Results are robust to a number of sensitivity checks.

JEL Classification: $\quad 111, \mathrm{I} 18$

Keywords: health reforms, self-assessed health

Corresponding author:

Lorenzo Cappellari

Department of Economics and Finance

Università Cattolica del Sacro Cuore

Largo Gemelli 1

I-20123 Milano

Italy

E-mail: lorenzo.cappellari@unicatt.it

\footnotetext{
We thank Francesco Moscone, Jonathan Skinner, and seminar participants at the IV Health Econometrics Workshop (University of Padua), the 2014 AIEL Conference (University of PISA) and the 2014 EALE Conference (University of Ljubljana) for helpful comments. Usual disclaimers apply.
} 


\section{Introduction}

Over the past two decades, many European governments have been (re-)introducing the 'market mechanism' in the public health care sectors in order to cope with various kinds of inefficiencies plaguing the hospital industry. The Netherlands and the UK adopted the model of 'quasi-markets' at the beginning of the Nineties for hospital services (e.g., Bartlett and Le Grand, 1993). The model requires, on the one hand, a public purchaser of services to contract with public and private suppliers for the services offered to citizens; on the other hand, citizens are free to choose the producer from which to obtain the service they need. While supporters of market incentives underline the potential efficiency gains, opponents often worry about their negative impact on the quality of service provided and the health of patients.

Italy adopted the 'quasi-markets' model at the beginning of the Nineties. The expected result was an improvement in efficiency, which could help the country, subject to a severe financial crisis, to meet the requirements imposed by the Maastricht Treaty to public finances. Besides modifying the organization of health care services delivery, the reform introduced a prospective payment system (PPS) based on Diagnosis-Related Groups (DRGs), similar to the US one. However, in Italy, unlike the UK where the NHS is highly centralized, regions were in charge of implementing the reform, leading to variation in regulations across regions. Moreover, information about service quality was - and to large extent still is - virtually unavailable, making the option of quality reduction a potential problem.

What has been the impact of this Italian reform on health outcomes? Despite the centrality of this question for assessing the comparative merits of different models of health care organization, there is still no evidence on the topic. This paper is a first attempt to provide an answer to such question. We exploit the differences between regions in the implementation timing of DRGs to assess their impact on a particular health outcome, self-assessed health status (SAH), which can be influenced both by changes in providers' behavior in terms of services supplied, and by how these 
changes are perceived from patients. We consider a survey of more than 600,000 individuals, over the years 1993-2007, which makes available information on both individuals' perceived health and their access to a number of health services.

Evidence on the impact of these pro-competitive reforms have been provided in recent years by a strand of literature reviewed in Gaynor et al. (2012). The general conclusion is that competition and, more generally, market incentives have a positive effect on health outcomes, in particular on the quality of health care services, but institutional details do matter. For instance, Propper et al. (2008), considering the first wave of reforms in the English National Health Service (NHS), find that hospitals in more competitive markets reduced the quality of care (here measured by the ' 30 day' death rate for Acute Myocardial Infarction, AMI) in order to cut waiting times. This result is explained by the fact that public information on quality was not available at that time, while waiting times were an important policy concern. Moreover, prices were negotiable between buyers and hospitals, and negotiations included results on waiting times, so that hospitals substituted less observable quality with more observable waiting times. On the contrary, Cooper et al. (2011), considering the second wave of reforms in the UK, find that quality (measured by the same AMI death rate) improved where competition was more fierce. This is due to the implementation of a new fixed-price funding mechanism called 'payment-by-results', largely mirroring the US PPS based on DRGs, and the provision of information about quality to patients.

Using a difference-in-differences approach which exploits the different timing of the reform's implementation in the Italian regions, and controlling for individual's characteristics (like gender, age and education) and for region and year fixed effects, our results suggest that the introduction of these market incentives does not lead to a worst health outcome. However, while no significant changes emerge in $\mathrm{SAH}$, the reform marked a moderate decrease in hospitalization (from -0.3 to 0.8 percentage points) and in day hospital attendance (-0.3 p.p.), coupled with a clear decrease in the access to emergency services ( -1.7 or -3 p.p., according to the time period considered). These 
reductions in the access to health services are stronger if we restrict the analysis to the immediate post intervention period, when the reform had full political support. We also consider a number of robustness checks and the potentially heterogeneous effects of the reform across different groups by age, gender, and education. In all cases our conclusions are largely confirmed. In addition, we do not find evidence that the reform increased household purchases of private health insurance.

The remainder of the paper is as follows. In Section 2 we provide essential background information on the Italian quasi-market reforms. In Section 3 we describe the data and our identification strategy. Results are discussed in Section 4, while Section 5 concludes.

\section{The Italian 'quasi-market' reforms}

The Italian NHS - enacted with Law 833 in 1978 - is a public universalistic scheme covering health care risks, and represents the central institution in the conduct of health care policy. Public health care spending in Italy reached about $7 \%$ of GDP in recent years, from $6 \%$ at the beginning of the '90s. Even spending less than other comparable public systems, the Italian NHS obtained good results in terms of the (average) quality of services provided, and rank among the top positions according to international evaluations of the overall performance by independent observers (see, e.g., the 2000 World Health Report by the WHO, or the recent exercise by Bloomberg ${ }^{1}$ ). In fact, the increase in spending has been paired with an improvement in population health, measured for instance by average life expectancy at birth: males gained about six years from the beginning of the Nineties, reaching 79.4 years; females expectations raised from 80 to 84.5 .

Since the Italian NHS is a regional health care system, health policy is the result of a complex network of institutional and political rules. The Constitutional mandate on health care (which dates back to 1948, and has been reformed in 2001) attributes to the Central Government: 1) the definition and the guarantee of Essential Levels of Care (Livelli Essenziali di Assistenza, or LEA,

\footnotetext{
${ }^{1}$ The complete ranking is available at http://www.bloomberg.com/visual-data/best-and-worst//most-efficient-healthcare-2014-countries.
} 
national mandatory standards for health services); 2) the responsibility for framework legislation; 3) the ultimate responsibility for health care financing. According to Constitution, regional governments are instead in charge of: 1) the organization and the provision of health services (e.g., the management of public hospitals and Local Health Units); 2) the provision of additional services with respect to the mandatory national standards (LEA). As there are 15 ordinary statute regions (plus 5 special statute regions), even in the presence of national mandatory standards, it is not surprising that there are territorial differences among regional governments along several dimensions, from the organization of health services provision to the reimbursement mechanism for hospitals. $^{2}$

The introduction of quasi-markets is due to the 1992-1993 reforms, a framework legislation by the Central Government that was inspired by similar developments in the British NHS in 1990. The explicit aim of the reform was to boost the productive efficiency of hospitals, and the overall efficiency of public spending in the sector (e.g., Turati, 2013). The move toward quasi-markets induced two basic changes in the organization of the NHS. First, the old Local Health Units (Unità Sanitarie Locali, USL; public bodies that jointly managed the tasks of insuring patients and of producing services) were transformed into Local Health Companies (Aziende Sanitarie Locali, ASL). In essence, the law designed a new type of publicly owned firm, with a strong focus on the efficient management of the budget. The transformation required a new internal organization for ASL, quite close to that of a private firm: a Board of Directors and a Chief Executive Officer, to be appointed by regional governments, and a Board of Statutory Auditors for internal audits. This is why the 1992-1993 reforms are often identified in Italy as the 'business-transformation' of the NHS. A second change, required by the move toward the quasi-market model, was to separate producers from purchasers of services. The basic implication here was for ASL to hive off

\footnotetext{
${ }^{2}$ Ordinary statute regions are: Abruzzo, Basilicata, Calabria, Campania, Emilia-Romagna, Lazio, Liguria, Lombardy, Marche, Molise, Piedmont, Puglia, Tuscany, Umbria, Veneto. Special statute regions are: Friuli-Venezia Giulia, Sardinia, Sicily, Trentino-Alto Adige, Valle d'Aosta.
} 
hospitals, and to create the so-called Aziende Ospedaliere (AO, literally Hospital Firms), public hospitals quite similar to the NHS Trusts of the UK reform. ASL were supposed to retain mostly administrative services (including the definition of needs at the local level), and then to contract with different producers (from newborn public AO to private hospitals) the services for all residents in their jurisdiction.

This fundamental change had different implications: since the ASL had to contract with producers, a price for the services to be purchased also needed to be defined. The solution proposed by the Central Government was to introduce a prospective payment system (PPS) based on Diagnosis Related Groups (DRG) which basically substituted per-day fees for private providers and full ex-post payment for public hospitals with a fixed price reimbursement mechanism for both types of producers. A national listing of tariffs was proposed by the Central Government in the decree of the Ministry of Health 14 December 1994 n. 169, but - coherently with the regional nature of the NHS - an opportunity was given to regional governments to adopt their own set of tariffs, more tailored to actual costs of their local producers. In any case, the new PPS had to be started between 1995 and 1997, and regions that did not set their own prices had to adopt the national ones, that were updated in the meanwhile with the decree of the Ministry of Health 30 June 1997 n. 178.

Given this national framework legislation, different regional governments replied in different ways, creating a large variability in the quasi-markets model at the local level. Only Lombardy separated all providers from purchasers, and adopted its own set of tariffs since 1997 (the so-called 'Lombardy model', Brenna, 2011). Other three regions defined their region-specific prices in 1997 (Emilia-Romagna, Tuscany and Umbria), followed by another one (Veneto) in 1998, but their organizational choice was to maintain the Local Health Firm as an integrated insurer-producer for almost all (if not all, in the case of Tuscany) hospitals (Ministero della Salute, 2013). 
The introduction of a region-specific set of tariffs is the key policy to implement the procompetitive reform designed in 1992-1993 by the National Government. As suggested by Di Loreto and Spolaore (2004), regional tariffs reflect more the provision of incentives for pursuing specific goals in the supply of hospital services than the 'efficient' costs for producing those services. Hence, we can assume that the Regional Governments that defined their own tariffs were also those that expected market incentives to work according to the baseline quasi-markets model.

Interestingly, while some regions believed in the potential improvements that can be gained via price incentives, after the initial years following the reform the 'quasi-market' model was abandoned by the Central Government in favor of a budget-based approach. The legislative decree 229/1999 is a framework legislation with which the Central Government reneged the benefits of competition in health care, and assumed a more centralist approach. While centralization was outdated, because Regional Governments already obtained a large degree of autonomy, the idea that competition has to be abandoned in order to control expenditure gained popularity among regions too. Also the 'Lombardy model' was then transformed in a 'quasi-administered' system, which sacrificed pure competition in favor of the budget based approach (Brenna, 2011). However, the budget-based approach has not sacrificed the DRG-based payment system for hospitals, which is still alive, and it is used to define budgets for hospitals, as well as the free choice for patients and the separation of insurers from producers. Price incentives can then still be used, and are still used by Regional Governments. Indeed, other three regions set their own set of tariffs in recent years: Sicily and Piedmont since 2002, and Lazio since 2005 (see, e.g., Carbone et al., 2006).

What has been the impact of the quasi-market reform on the activity of hospitals? Cerbo and Langiano (2004), after ten years from the original DM 169/94, identified four main trends in the Italian NHS, which paralleled the evolution of the hospital industry in other comparable European countries: 1) a significant reduction in the number of hospitals' beds for acute care; 2) an increasing substitution of inpatient with outpatient care; 3) a substantial decrease in the average length of stay 
for acute care; 4) an increase of the share of surgical admissions out of total admissions, which increases the complexity of care. While the reduction of the productive capacity of the hospital industry is the result of ever more stringent standards fixed by the Central Government, the remaining three trends are guided by the price incentives provided by the introduction of the quasimarket model, and - in particular - by the DRG-based payment system.

This evidence is based on national aggregate data, while regional governments did play a role in defining different market incentives for their hospitals, resulting in different trends with respect for instance to the substitution of inpatient with outpatient care. Do these changes had any real impact on $\mathrm{SAH}$, or do they just contribute to wipe out inefficiencies? Is the impact more pronounced in regions that adopted their own set of tariffs in order to tailor more finely price incentives for their hospitals? These are the questions we ask in the empirical analysis that follows.

\section{Data and identification strategy}

We use individual level data to explore whether the introduction of region-specific tariffs had any impact on SAH and on health care services utilization. We draw data from the Survey on the Daily Life of Italian Households (Indagine Multiscopo sulle Famiglie) which has been run annually (with the exception of year 2004) by the National Statistical Institute (ISTAT) since 1993. The survey covers a rich set of demographic controls, and provides information on several aspects of the everyday life of Italian households, from dwelling conditions to education, health status, labour market behaviour, transportation and time use. The sample is designed to represent the population of Italian households. The sampling unit is the household, and information is available both at the household and individual level. Each year, a sample of nearly 20,000 households (about 60,000 individuals) is interviewed. For the purposes of our analysis, we select individuals older than 15, 
yielding a sample of about 660,000 observations over 14 waves (1993-2007). ${ }^{3}$ We use survey stratification weights throughout the analysis.

The survey contains identifiers of the region of residence which is crucial for our analysis because it enables us to allocate individuals to treatment and control groups according to the survey year and region of residence, following the staggered-by-region design of the reform implementation. In particular, our treatment is defined by the adoption at the regional level of a set or region-specific DRG tariffs as alternative to those defined at the national level. Clearly, the introduction of a set of DRG tariffs is only part of the wider set of policy interventions aimed at increasing efficiency in the health care sector by adopting the quasi-market model that were carried out by the Italian regions in the same years. But, as we discussed above, regional governments implementing their own tariffs are more keen at exploiting the working of the market mechanism, via price incentives for producers. Within the national framework that required the adoption of the centrally defined tariffs by 1997 , the timing of implementation of regional specific DRG prices and thus of the pro-competitive reform of the health care system - varies across regions, see Table 1, allowing the identification of the effects of the reform in a difference-in differences (Diff-in-diff) set-up.

\section{[TABLE 1 AROUND HERE]}

Our baseline specification models the effect of the reform as follows:

$$
Y_{i r t}=\alpha+\beta R_{r t}+x_{i r t}^{\prime} \gamma+\delta_{r}+\tau_{t}+\varepsilon_{i r t}
$$

\footnotetext{
${ }^{3}$ Available data span through to 2012 . We do not use data from 2008 and onwards due to a change in the wording of the question on self-assessed health, our main variable of interest. While the change affected unconditional statistics, robustness checks including 2008-2012 data produced estimation results that were virtually identical to the ones presented in the paper.
} 
where $i, r$ and $t$ stand for individuals, regions and years, respectively. $Y_{i r t}$ represents the individual outcome of interest; $R_{r t}$ is a dummy variable equal to 1 if region $r$ implemented its own regionspecific tariffs in year $t$ or earlier, thus capturing exposure to treatment; $x_{i r t}$ is a set of control variables for individuals' socio-demographic characteristics (age and its square, gender, education); $\delta_{r}$ and $\tau_{t}$ are region and year fixed effects which ensure that the variation in $R_{r t}$ does not reflect time-invariant regional heterogeneity or secular trends common across regions; finally, $\varepsilon_{i r t}$ is a white noise error term. ${ }^{4}$ The main parameter of interest is the coefficient $\beta$ associated with the treatment dummy. Conditional on the common trend assumption, a negative estimate of $\beta$ would imply that the adoption of regional price mechanisms exerts a detrimental causal effect on individual outcomes.

The Multiscopo survey reports information about several variables that are of interest to our analysis as individual outcomes $Y$ that are potentially affected by the reform of the health system. Specifically, we focus primarily our attention on $\mathrm{SAH}$ as main indicator of individual health status. Moreover, as the effects on health status might operate through the utilization of health care services, we also study access to day hospital and emergency room (ER) treatments, as well as ordinary hospitalization and satisfaction with the service for those hospitalized. In order to check whether the reform induced individuals to substitute public health services with private ones thereby compensating for any negative effect of the reform on health perceptions-we additionally consider indicators for whether at least one family member has a private health insurance. Since it is not clear from the questionnaire whether the insurance covers the household's head, all members or just some of them, the unit of analysis in this case will be the household and not the individual. Finally, we complement the analysis with objective health indicators such as average life expectancy (ALE) and infant mortality rate (IMR), measured at the regional level, which are

\footnotetext{
${ }^{4}$ In estimation we cluster standard errors by region and year so as to allow for correlation across time and space.
} 
commonly used in the literature as proxies for health status (e.g., Piacenza and Turati, 2014; Baltagi et al., 2012, Akkoyunlu et al., 2009, Hall and Jones, 2007, Papageorgiou et al., 2007, Crémieux et al., 2005, Shaw et al., 2005) and are made available by ISTAT in the Health For All Survey, covering years 1993-2007.

Descriptive statistics for all these variables are in Table 2. The first column reports means on the entire sample. Columns 2 and 3 show mean values of the outcomes according to treatment status. Column 4 to 6 break up the data into three sub-periods: pre-reform (1993-1997), first reform period (i.e. the one with full support from the central Government, 1997-1999) and second reform period (2000-2008).

\section{[TABLE 2 AROUND HERE]}

The main outcome variable is self-assessed health status, which is derived from a survey question asking respondents to rate their feeling about their overall health status on a 5-point scale, where 1 means "very bad" and 5 means "very good". We convert the original SAH variable into a binary indicator equal to one for scores equal to "good" $(=4)$ or "very good" (=5) so that we can use linear probability models to retrieve the effects of the treatment on the likelihood of rating own health at least as good. ${ }^{5} \mathrm{SAH}$ is a commonly used summary measure for general health, that has been shown to be strongly correlated with morbidity and mortality and with other objective measures of health, such as limitations in functioning, level of energy and physical symptoms (among others, Idler, 1992; Idler and Benyamini, 1997; Kennedy et al., 1998). On average the health status does not vary much over time (columns 4 to 6 ) and over the treatment status (columns 2 and 3). In Figure 1, Panel a), we represent the variation in SAH over time and by treatment

\footnotetext{
${ }^{5}$ Results are robust to a number of alternative choice of specification including probit and logit regressions on the binary indicator, ordered probit and logit regressions on the original 5-point scale variable, and linear probability, probit and logit regressions on a binary indicator for poor health (i.e. a dummy for $\mathrm{SAH}=1$ or $\mathrm{SAH}=2$ ).
} 
groups: these unconditional averages do not show any evident change after the reform was implemented. On the other hand, health service utilisation seems to be affected differentially across treatment status, particularly access to emergency room (Panel b)).

\section{[FIGURE 1 AROUND HERE]}

While SAH has been widely used in the literature, its ability in capturing true health status may be limited in a number of directions. For instance, Franks et al. (2003) show that self-rated health is systematically influenced by personal characteristics such as gender, age, ethnicity, education and income. Bauhoff (2011) illustrates that controlling for information on health issues make in fact SAH more closely related to objective health, reducing respondents' overestimation of their own health status. In our study we will limit these biases controlling for all the sociodemographic factors available in the survey and also for habits that may potentially be related with individual health, such as smoking and drinking.

We will also analyse additional outcomes that characterize the individuals' experience in the access of health care services, namely whether they use ER, a day hospital service, or an ordinary hospitalization. ${ }^{6}$ These outcomes are binary indicators, equal to 1 if the individual ever used the service at least once in the last three months. ${ }^{7}$ For those that have been hospitalized we also consider a binary indicator for whether they were satisfied with the services provided by the doctors during hospitalization. These are all outcomes that might have been related to the reform's attempts to reduce health care service expenditures. The descriptive statistics in Table 2 (columns 4 to 6) show indeed that in the post reform period there is a strong reduction in the use of health care services, see also Figure 1, Panels b) and c). The reform's effect is also evident looking at columns

\footnotetext{
${ }^{6}$ The question about day hospital use was administered until 1999.

${ }^{7}$ In some survey years the reference period was 12 months (1993, 1995 and 1997) but since the analysis is focused on the variation in the health care services use between regions the change in the reference period is not a relevant to us.
} 
2 and 3, namely comparing the regions according to their treatment status. We can also notice from the Table that private insurance ownership slightly increased over time and in the treated regions; moreover, ALE and IMR, seems to be improving over time (col 4,5 and 6) and in the treated regions (col 2 and 3).

As already mentioned, the baseline specification laid out in (1) identifies the causal effect of the reform on individual outcomes conditional on the common trend assumption. We will subject the assumption to robustness checks in the next section by augmenting the baseline specification with region-specific time trends. We will also consider treatment heterogeneity by estimating the specification in (1) on sub-samples defined according to socio-demographic characteristics.

\section{[TABLE 3 AROUND HERE]}

\section{Results and discussion}

\subsection{Baseline results}

Table 3 reports results from the estimation of equation (1) using as outcomes either SAH, health services utilization (ER, day hospital and hospitalization) and satisfaction with health care services. We estimate these regression controlling for demographics (age, gender and education) and additionally adding controls for health-related habits (smoking and drinking), employment status and type of occupation (to proxy income that is not available in the survey); as the inclusion of the additional controls does not alter the substance of the results, we present regression output from the more parsimonious specification. The model is estimated on 4 different samples, and results for each sample are reported in each of the four panels of the table. Panel A refers to the full sample; Panel B excludes late adopting regions (Piedmont, Sicily and Lazio); Panel C considers only the period up to 1999 (which both has data on day hospital utilization and is the era of full support to 
the reform by the central Government); and Panel D excludes late adopting regions and uses the sample that stops in 1999.

Estimates in Panel A show no significant effect of the reform on SAH, while it clearly negatively affected the probability of accessing the ER (-1.7 percentage points, p.p. henceforth) and also slightly reduced hospitalization (-0.3 p.p.); there is also a marked reduction in satisfaction with overall hospital treatment for those that have been hospitalized, -2.5 p.p.. Before the reform, the average ER attendance rate was about $12 \%$, meaning that the intervention reduced the ER access by $25 \%$; following the same reasoning the reduction in hospitalization was $10 \%(0.3 / 3)$.

These results are obtained on the sample that includes regions adopting the reform in the 2000s, after the overall political orientation changed in favor of a budget-based approach. It is plausible to think that inclusion of these late adopters mitigates the effects of the reform. Indeed, results in Panel B - which excludes late adopters-point to stronger negative effects of the reform on both services utilization and satisfaction with services, but still there is no significant impact of the reform on SAH. The effect of the reform is stronger also if we restrict the analysis to the immediate post intervention period when the reform had full political support and consider all regions together, see Panel C. Again there is no evidence that the reform reduced SAH, but, if anything, the effect was small and positive, +1 p.p. on the probability of reporting "good" or "very good" health status. We can also see here that effects on the use of day hospital have the same negative sign as the ones on the use of other health services. Combining the early adopters sample with the sample from the era of full political support in Panel D just confirms what we have already seen so far that the reform reduced the utilization of health care services and the satisfaction with those services for those that used them, but did not exert any impact on health perceptions. ${ }^{8}$

Overall, these results suggest that while SAH remains unchanged, the use of health care services is reduced substantially, possibly meaning that before the reform the use of health care

\footnotetext{
${ }^{8}$ As a separate check robustness check we repeated the analysis on the sample of individuals that have been hospitalized, finding again no effect of the reforms on SAH.
} 
services was disproportionate with respect to actual needs. The reform triggered an improvement in the efficiency of health spending without altering the quality of the services supplied and the provision of services really needed by citizens.

\subsection{Robustness checks}

In what follows we extend the analysis in different ways. First we amend the baseline specification adding region-specific trends, so as to relax the common trend assumption underlying the diff-indiff results in Table 3. Then we consider ALE and IMR, to see whether the absence of reform effects on health also applies to objective measures of health conditions. Since ALE and IMR data are defined at the regional level, we will repeat also the baseline analysis of Table 3 on data aggregated at the regional level to provide a benchmark. Private health insurance ownership is also taken into account as individuals may have substituted publicly provided services with private ones. This is checked using also the region specific trend augmented specification. Finally, we conduct the main analysis by birth cohort to see whether reform effects reflect differences across individuals that grew up under different national health policy regimes (in particular young cohorts growing up with the Italian NHS established in 1978).

Region-specific trends. Our baseline specification controls for year and region fixed effects, but there could be region-specific trends in SAH and in the use of health care services that could be confounded with the reform and that we are not capturing. For example, in treated regions individuals may modify the subjective evaluation of their health status changing their reference point and adapting it to what they perceive to be the standard for health conditions. In this circumstance, our analysis would detect any effect of the reform on SAH even if individuals' health status actually deteriorated. ${ }^{9}$

\footnotetext{
${ }^{9}$ The vignette-anchoring method (see, for example, Kapteyn et al., 2007, or the papers in the Journal of the Royal Statistical Society - Series A, introduced by Arnaud and Fielding, 2011) would be helpful in this case, but those kind of questions are not administered in our survey.
} 


\section{[TABLE 4 AROUND HERE]}

To account for these possibilities, we augment the baseline specification in equation (1) with the interactive term between the region dummy variables and a linear trend. The results show that the reform's impact is less strong with respect to both ER access and hospitalization, but no change in SAH emerges. The Day Hospital reduction is actually slightly stronger in this more demanding specification. Overall the estimates confirm our previous findings: if anything regional trends should not have been played an important role in changing individuals' behavior and SAH in the years of the reform, see Table 4 .

Objective measures of health. Our SAH measure of health is definitely subjective so that despite the large literature suggesting a clear link between subjective and objective measures - our results could still be biased by subjective feelings. In order to overcome this problem we consider two more objective indicators of population health, like the IMR and the $\mathrm{ALE}^{10}$.

\section{[TABLE 5 AROUND HERE]}

Table 5 illustrates the reform's effect on these two objective health status indicators; since we use data aggregated at the regional level we also replicate the analysis with the baseline outcomes. Results clearly show that the reform's effect is identical to the one estimated by equation (1) and that the impact on the objective outcome is almost never different from zero. Since both ALE and IMR can respond to a shock such as the reform under analysis with some delay (as discussed, e.g.,

\footnotetext{
${ }^{10}$ These two variables can also help to - at least partially - address the problem of selection, i.e., the fact that the survey is administered to people who are alive, and not to people who died as the result of introducing the quasi-market model. In particular, while ALE admittedly captures also a number of factors not directly related to health care, IMR is more directly linked to variables under the control of hospitals (like the choice of vaginal versus caesarean delivery). Francese et al. (2014) provides evidence that DRG tariffs influence the inappropriate use of caesarean sections in the Italian NHS.
} 
by Piacenza and Turati, 2014) we also test if this is the case pretending that the reform was implemented from 1 to 3 years later. The results (not shown here) confirm that the reform's effect was never different from zero.

Substitution of public with private services. A third concern is related to the fact that individuals might have been forced to substitute public services with private ones. While we are still lacking a clear model rationalizing the relationships between public and private health care spending (e.g., Levaggi and Turati, 2010), this likelihood can clearly bias our results: competition fueled by the new reimbursement mechanism brought about a reduction in the provision of services by public hospitals, which further resulted in an increased demand of private services; these are the services that allowed no change in SAH. To check for this issue, missing a direct measure of out-ofpocket spending and of the use of private services, we consider the demand for private health insurance.

\section{[TABLE 6 AROUND HERE]}

The change in private health insurance subscription (Table 6) is estimated in two ways: first with region and year fixed effects only (columns 1 and 3) and then with also region specific trends (columns 2 and 4). Overall, subscription rates are not affected by the reform, and thus there is no evidence of an increase in the use of private health insurance to compensate for a potential lack in the provision of public health care services.

A cohort-wise analysis. As briefly explained in the institutional section above, in 1978 there was a radical change in the organization of the Italian public health care service: a public universalistic scheme substituted a highly fragmented system of insurance funds, mainly reflecting the corporative nature of the Italian Welfare State (e.g., Turati, 2013). It is then interesting to explore if there are variations in individuals' perception of their health that depend on the different 
'organizations' of the public health care schemes that they might have experienced during their lifetime. Individuals born before 1948 - and thus aged at least 30 in 1978 - are those that potentially used the health care services before 1978, and thus may react differently to the 1997 reform with respect to those that did not use the health care service before 1978 .

\section{[TABLE 7 AROUND HERE]}

The baseline specification of Equation (1) is amended introducing an interaction term between the reform and a dummy variable which identifies those that are born before 1948. The results are in Table 7. Perhaps surprisingly, SAH improves with the treatment for those that were born before 1948, while it gets relatively worse for those born after 1978. The decrease in hospitalization is clearly driven by the older cohort (-2 p.p.), while the ER access and Day Hospital services use decrease uniformly for all the sample. The decrease in hospitalization is probably driven by the fact that hospitalization was far more frequent for those that were born before 1948 (12\% vs. 6\%). Overall the results do not show important differences in the way people react to the reforms, at least according to the organization of the health care system they experienced in their lifetime. It is reassuring that those who can better compare the reformed health system with previous 'regimes' are not those that see a deterioration in health status.

\subsection{Heterogeneity by age, sex, education and region}

In this section, we explore the heterogeneous effects of the reform according to age, gender and educational attainment, so as to provide an understanding on whether the absence of reform effect on SAH is actually the result of opposing effect on different demographic group cancelling each other out. We then estimate Equation (1) running separate regressions for each of the groups considered. 
Heterogeneneity by age groups. If the reform was effective in improving efficiency, the reduction in health care costs should be differentiated according to the people's needs, namely it should target those individuals that are less at risk, so to decrease costs but not health. Since people's health status and health care use depend crucially on age, investigating age-related heterogeneities can be helpful for shedding light on the way efficiency is reached. We divide the sample in age groups that roughly correspond to education/training age (younger than 25), working age (from age 25 to 64 ) and pension age (older than 64). Then we also split the working age in two smaller groups: 25-44 years old and 45-64 years old, so to better capture differences in health care use and health status that may be depend on both individuals' age and career stages.

\section{[TABLE 8 AROUND HERE]}

Results are in Table 8. Overall, the reform's effect is stronger in the short run as in our previous results and it is clearly decreasing with age for ER access. SAH is not negatively affected by the reform in any age groups considered, if anything it is increasing for those aged 25-44. Young people, less exposed to health problems with respect to old people, experience the sharpest drop in ER access (-4.9 p.p. vs. -3 p.p. or -1.3 p.p. in the short run, while -3 p.p. vs. -1.6 pp. or -0.9 p.p. in the long run). The reduction in ER access by young and potentially healthy individuals is consistent with the aim of the reform, as the cost saving strategy implies a reduction of inappropriate services, presumably higher for individuals that are less at risk. For hospitalization and Day Hospital the differences among the groups are less clearly shaped. The age group that responds mostly to the intervention is composed by people aged 45-64. Again the reform seems to target users (young people are rarely hospitalized), but not those that would be harmed by a reduction in both hospitalization and Day Hospital. In fact those above age 64 are not affected by the treatment, even if they are those that use Day Hospital and hospitalization more. 


\section{[TABLE 9 AROUND HERE]}

Heterogeneneity by gender. The reform effect is quite similar across genders and coefficients are different because the health care use is different between males and females, see Table 9. In fact before 1997, the share of males that accessed ER services was 14\%, while for female it was $10 \%$. So the estimated reduction is proportional between the two groups $(2 / 14$ is identical to $1.4 / 10$, short run results, and $3.5 / 14$ is identical to $2.5 / 10$, long run results). For the probability to be hospitalized results show that while males are the group less at risk of hospitalization they are those that experience the stronger decline. In fact before 1997, $8.7 \%$ of males were hospitalized at least once in the last 3 month, while the share for females was $9.6 \%$. Therefore, the reduction with respect to hospitalization is not proportional (1/8.7 is different from 0.7/9.6), but the differences are not relevant. Overall, males and females are affected almost equally by the reform and since there is no reason to believe that there should be a difference in the reform's impact according to gender, we consider this exercise as a further confirmation of our identification strategy.

\section{[TABLE 10 AROUND HERE]}

Heterogeneity by education. Individuals with different education (hence cognitive skills and, potentially, income) may react differently to the reforms in the health care system. To explore this issue we divide our sample in three groups according to the highest level of education achieved: compulsory, higher secondary and tertiary education. Results are in Table 10. The reduction in the ER access is stronger the higher is the educational level in the short run, while in the long run these differences attenuate. The reduction is not proportional as the frequency of ER access is higher for 
less educated people. People with no more than compulsory schooling are those that on average are older (56 years old vs. 43 in the two other categories) and this may explain this finding (older people are those that are less affected by the reform). Also for Day Hospital use, less educated people are the group that experience the weaker reduction.

Education seems to be a factor that interacts with the reform, as the less educated group is the one that modified less the health care services use. In terms of SAH, there is no effect in any of the groups considered, so the reduction in health care services use and in health status seem to be not related at all.

\section{[TABLE 11 AROUND HERE]}

Heterogeneity by region. In order to explore whether the reform's effect was different across different regions, we interact the variable picking up the reform with regional dummy variables. Results are reported in Table 11. Considering the short-run impact of the reform, before the 1999 change in Central Government policy with respect to the quasi-market model, regions appear to be homogeneous with respect to the reduction in ER attendance and hospitalization (with the exception of Veneto), while the reduction in the use of day hospital is relevant only in Emilia-Romagna and Umbria. More importantly, $\mathrm{SAH}$ is never affected negatively by the reform, yet it is increasing in some regions. However, when considering a longer time span, some heterogeneity across regions emerges: in particular, the latecomers regions that adopted their own version of the DRG in 2002 and 2005 (Piedmont, Lazio and Sicily) perform very poorly with respect to the efficiency goal implicit in the introduction of fixed prices for hospital treatments. In Sicily SAH actually decreased while services use increased. In Lazio there was a reduction in SAH even if nothing happened to the services use, while in Piedmont nothing is changed by the adoption of region specific tariffs. Veneto is overall reducing expenditures at the expenses of individual's health, so it is not clear form 
these data whether the benefits from the reduction in costs offset the reduction in SAH or not. On the contrary, the first regions that adopted their own DRG tariffs in 1997 (Lombardy, EmiliaRomagna, Umbria and Tuscany) were those that increased efficiency by reducing access to services, while having no measurable effect on their citizens' health.

\section{Concluding remarks}

This paper provides the first assessment of the Italian DRG reforms of the 1990s based on microdata. Exploiting the staggered implementation of these reforms across regions we evaluate their impact on both subjective-assessed health $(\mathrm{SAH})$ and on self-reported utilization of health care services by means of a difference-in-differences design. Our headline findings indicate that while SAH was unaffected, the access and utilization of publicly provided health services were diminished.

These results, which are robust to a number of sensitivity checks, are consistent with the idea that pre-reform health care services were likely to be over-utilized by patients and that the reforms have increased the overall efficiency of the health care system via the use of price incentives allowed by the introduction of a quasi-market model in the Italian NHS. 


\section{References}

Akkoyunlu S., Lichtenberg F., Siliverstovs B., Zweifel P. (2009), "Spurious correlation in estimation of the health production function: a note", Economics Bulletin, 30(3), 2505-2514.

Baltagi B., Moscone F. and Tosetti E. (2012), "Medical technology and the production of health care”, Empirical Economics, 42(2), 395-411.

Bartlett W., Le Grand, J. (1993), Quasi-markets and Social Policy, Palgrave Macmillan.

Bauhoff S. (2011), Systematic self-report bias in health data: impact on estimating cross-sectional and treatment effects, Health Services and Outcomes Research Methodology, Vol. 11(1-2), pp. 44-53.

Brenna E. (2011), Quasi-market and cost containment in Beveridge systems: The Lombardy model of Italy, Health Policy, 103, 209-218.

Carbone, C., Jommi, C., A. Torbica (2006), Tariffe e finanziamento dell'innovazione tecnologica: analisi generale e focus su due casi regionali, in Anessi Pessina, E. and E. Cantù (eds.), Rapporto OASI 2006 - L’aziendalizzazione della Sanità in Italia, EGEA.

Cerbo M., Langiano T. (2004), L'impatto a livello nazionale del sistema di remunerazione, in Falcitelli N. and Langiano T. (eds.), Politiche innovative del Ssn: i primi dieci anni dei Drg in Italia, Il Mulino.

Chevalier A., Fielding A. (2011), An introduction to anchoring vignettes, Journal of the Royal Statistical Society - Series A, 174, 569-574.

Cooper Z., Gibbons S., Jones S., McGuire A. (2011), Does hospital competition save lives? Evidence from the English NHS Patient Choice Reforms, Economic Journal, 121: F228F260. 
Crémieux P-Y., Mieilleur M-C., Ouellette P., Petit P., Zelder P. and Potvin K. (2005), Public and private pharmaceutical spending as determinants of health outcomes in Canada, Health Economics, 14, 107-116.

Di Loreto P., Spolaore P. (2004), L'evoluzione del sistema nelle politiche regionali, in Falcitelli N. and Langiano T. (eds.), Politiche innovative del Ssn: i primi dieci anni dei Drg in Italia, Il Mulino.

Duggan M. (2000), Hospital Ownership and Public Medical Spending, Quarterly Journal of Economics, 1343-1374.

Francese M., Piacenza M., Romanelli M., Turati G. (2014), Understanding Inappropriateness in Health Spending: The Role of Regional Policies and Institutions in Caesarean Deliveries, Regional Science and Urban Economics, forthcoming.

Franks P., Gold M. R., Fiscella K. (2003), Sociodemographics, self-rated health and mortality in the US, Social Science and Medicine, Vol. 56, pp. 2505-2514.

Gaynor M., Moreno-Serra R., Propper C. (2012), Can competition improve outcomes in UK health care? Lessons from the past two decades, Journal of Health Services Research \& Policy, 17: 49-54.

Hall R. and Jones C. (2007), "The value of life and the rise in health spending", Quarterly Journal of Economics, 122, 39-72.

Idler E.L. (1992), Self-assessed health and mortality: a review of the studies, International Review of Health Psychology, 33-54.

Idler E.L., Benyamini Y. (1997). Self-rated health and mortality: a review of twenty-seven community studies. Journal of Health and Social Behavior, 38, 21-37.

Kapteyn A., Smith J. P., van Soest A. (2007), Vignettes and self-reports of work disability in the United States and the Netherlands, The American Economic Review, Vol. 97(1), pp. 461-473. 
Kennedy B.P., Kawachi I., Glass R. \& Prothrow-Stith D. (1998). Income distribution, socioeconomic status, and self rated health in the United States: Multilevel analysis. British Medical Journal, 317, 917-921.

Kornai J. (2009), The soft budget constraint syndrome in the hospital sector, International Journal of Health Care Finance and Economics, 9, 117-135.

Levaggi R., G. Turati (2010), Spesa sanitaria pubblica e privata: sostituti o complementi?, in C. De Vincenti, R. Finocchi Ghersi, A. Tardiola (a cura di), La Sanità in Italia, Bologna: Il Mulino, 447-460.

Ministero della Salute (2013), Annuario statistico del Servizio Sanitario Nazionale Anno 2010, Roma.

Papageorgiou C., Savvides A. and Zachariadis M. (2007), "International medical technology diffusion”, Journal of International Economics, 72, 409-427.

Piacenza M., Turati G. (2014), Does Fiscal Discipline towards Sub-national Governments Affect Citizens' Well-being? Evidence on Health, Health Economics, 23 (2), 199-224.

Propper C., Burgess S., Gossage D. (2008), Competition and quality: evidence from the NHS Internal Market 1991-9, Economic Journal, 118: 138-170.

Shaw J., Horrace W. and Vogel R. (2005), "The determinants of life expectancy: an analysis of the OECD health data", Southern Economic Journal, 71, 768-783.

Turati G. (2013), The Italian Servizio Sanitario Nazionale: a renewing tale of lost promises, in J. Costa-Font and S. C. Greer (eds.), Federalism and Decentralization in European Health and Social Care: Competition, Innovation, and Cohesion, Palgrave MacMillan, 47-66. 
Table 1 - The Introduction of region-specific tariffs

\begin{tabular}{lc}
\hline & Year of the reforms \\
Piedmont & 2002 \\
Lombardy & 1997 \\
Veneto & 1998 \\
Emilia-Romagna & 1997 \\
Tuscany & 1997 \\
Umbria & 1997 \\
Lazio & 2005 \\
Sicily & 2002 \\
\hline
\end{tabular}

Table 2 - Mean values of the outcomes

\begin{tabular}{lcccccc}
\hline & $(1)$ & $(2)$ & $(3)$ & $(4)$ & $(5)$ & $(6)$ \\
& Total & No treatment & Treatment & $<1997$ & $1997-1999$ & $>1999$ \\
\cline { 2 - 7 } Good health & 0.72 & 0.73 & 0.71 & 0.72 & 0.73 & 0.72 \\
ER (y/n) & 0.08 & 0.09 & 0.07 & 0.12 & 0.06 & 0.07 \\
Day Hospital (y/n) & 0.03 & 0.03 & 0.03 & 0.03 & 0.02 & \\
Hospitalization (y/n) & 0.05 & 0.06 & 0.04 & 0.09 & 0.04 & 0.04 \\
Sat docs if hosp (1-4) & 3.24 & 3.21 & 3.31 & 3.24 & 3.22 & 3.24 \\
Fully satisf by docs if hosp & 0.36 & 0.34 & 0.42 & 0.36 & 0.36 & 0.36 \\
ALE & 79.5 & 79.2 & 80.5 & 78.1 & 78.9 & 80.6 \\
IMR & 47.1 & 50.6 & 35.8 & 61.5 & 51.3 & 37.1 \\
Private insurance ownership & 0.25 & 0.23 & 0.3 & 0.23 & 0.24 & 0.26 \\
Treatment & 0.35 & & & 0.00 & 0.36 & 0.55 \\
\hline
\end{tabular}

Note: Satisfaction of the service provided by the doctors (in case of hospitalization) is coded as a binary indicator equal to 1 if the individual reported a value of 4 , on a 1 to 4 rating scale. The 'treatment' category identifies treated regions, in the post reform period. Source: Multiscopo Survey (ISTAT), 1993-2007. 
Table 3 - Baseline estimates

\begin{tabular}{|c|c|c|c|c|c|}
\hline & $\mathrm{SAH}$ & $\begin{array}{c}\text { (2) } \\
\text { Emergency } \\
\text { Room access }\end{array}$ & $\begin{array}{l}\text { (3) } \\
\text { Day Hospital } \\
\text { access }\end{array}$ & Hospitalization & $\begin{array}{l}\text { (5) } \\
\text { Satisfaction } \\
\text { with the service } \\
\text { if hospitalized }\end{array}$ \\
\hline & \multicolumn{5}{|c|}{ Panel A: 1993-2007 } \\
\hline treatment & $\begin{array}{l}-0.002 \\
(0.003)\end{array}$ & $\begin{array}{c}-0.017 * * * \\
(0.003)\end{array}$ & & $\begin{array}{l}-0.003 * \\
(0.002)\end{array}$ & $\begin{array}{c}-0.025^{* *} \\
(0.012)\end{array}$ \\
\hline $\begin{array}{l}\text { Observations } \\
\text { R-squared }\end{array}$ & $\begin{array}{c}660,326 \\
0.253 \\
\end{array}$ & $\begin{array}{c}663,894 \\
0.016 \\
\end{array}$ & & $\begin{array}{c}665,660 \\
0.030 \\
\end{array}$ & $\begin{array}{c}34,726 \\
0.066 \\
\end{array}$ \\
\hline treatment & $\begin{array}{l}-0.001 \\
(0.003)\end{array}$ & $\begin{array}{c}\text { B: 1993-200 } \\
-0.033 * * * \\
(0.004)\end{array}$ & Piedmont, Laz & $\begin{array}{c}\text { and Sicily exclu } \\
-0.008 * * * \\
(0.003)\end{array}$ & $\begin{array}{l}\text { ded } \\
\qquad-0.038 * * * \\
(0.014)\end{array}$ \\
\hline $\begin{array}{l}\text { Observations } \\
\text { R-squared }\end{array}$ & $\begin{array}{c}523,412 \\
0.249 \\
\end{array}$ & $\begin{array}{c}525,874 \\
0.018 \\
\end{array}$ & & $\begin{array}{c}527,273 \\
0.031 \\
\end{array}$ & $\begin{array}{c}28,016 \\
0.067 \\
\end{array}$ \\
\hline treatment & $\begin{array}{c}0.010 * * \\
(0.004)\end{array}$ & $\begin{array}{c}-0.030 * * * \\
(0.004)\end{array}$ & $\begin{array}{c}\text { nel C: } 1993-1 \\
-0.003 * * \\
(0.002)\end{array}$ & $\begin{array}{c}-0.008 * * * \\
(0.002)\end{array}$ & $\begin{array}{l}-0.030 \\
(0.019)\end{array}$ \\
\hline $\begin{array}{l}\text { Observations } \\
\text { R-squared }\end{array}$ & $\begin{array}{c}354,296 \\
0.255 \\
\end{array}$ & $\begin{array}{c}355,610 \\
0.021 \\
\end{array}$ & $\begin{array}{c}351,700 \\
0.005 \\
\end{array}$ & $\begin{array}{c}357,134 \\
0.031 \\
\end{array}$ & $\begin{array}{c}23,576 \\
0.068 \\
\end{array}$ \\
\hline treatment & $\begin{array}{c}0.005 \\
(0.004)\end{array}$ & $\begin{array}{c}\text { D: } 1993-199 \\
-0.031 * * * \\
(0.005)\end{array}$ & $\begin{array}{c}\text { Piedmont, Laz } \\
-0.004 * * \\
(0.002)\end{array}$ & $\begin{array}{c}\text { and Sicily exclu } \\
-0.007 * * \\
(0.003)\end{array}$ & $\begin{array}{l}\text { ded } \\
\qquad \begin{array}{c}-0.039 * * \\
(0.020)\end{array}\end{array}$ \\
\hline $\begin{array}{l}\text { Observations } \\
\text { R-squared }\end{array}$ & $\begin{array}{c}279,975 \\
0.252\end{array}$ & $\begin{array}{c}280,941 \\
0.023\end{array}$ & $\begin{array}{c}278,080 \\
0.005\end{array}$ & $\begin{array}{c}282,149 \\
0.032\end{array}$ & $\begin{array}{c}19,085 \\
0.068\end{array}$ \\
\hline
\end{tabular}

Notes: all estimates control for age and its square, gender and educational level. Region and year fixed effects are also included. Robust standard errors are in parentheses, clustered at the year-region level. $* * * \mathrm{p}<0.01, * * \mathrm{p}<0.05, * \mathrm{p}<0.1$ 
Table 4 - Estimates with region specific trend

\begin{tabular}{|c|c|c|c|c|c|}
\hline & (1) & $\begin{array}{c}(2) \\
\text { Emergency } \\
\text { Room access }\end{array}$ & $\begin{array}{c}\text { (3) } \\
\text { Day Hospital } \\
\text { access }\end{array}$ & Hospitalization & $\begin{array}{l}\text { (5) } \\
\text { Satisfaction } \\
\text { with the service } \\
\text { if hospitalized }\end{array}$ \\
\hline & \multicolumn{5}{|c|}{ Panel A: 1993-2007 } \\
\hline treatment & $\begin{array}{c}0.002 \\
(0.004)\end{array}$ & $\begin{array}{c}-0.014 * * * \\
(0.003)\end{array}$ & & $\begin{array}{c}-0.004 * * \\
(0.002)\end{array}$ & $\begin{array}{l}-0.018 \\
(0.016)\end{array}$ \\
\hline $\begin{array}{l}\text { Observations } \\
\text { R-squared }\end{array}$ & $\begin{array}{c}660,326 \\
0.253 \\
\end{array}$ & $\begin{array}{c}663,894 \\
0.017 \\
\end{array}$ & & $\begin{array}{c}665,660 \\
0.030 \\
\end{array}$ & $\begin{array}{c}34,726 \\
0.067 \\
\end{array}$ \\
\hline treatment & $\begin{array}{c}0.008 \\
(0.007)\end{array}$ & $\begin{array}{l}-0.020 * \\
(0.010)\end{array}$ & $\begin{array}{c}\text { nel B: 1993-19 } \\
-0.005^{*} \\
(0.002)\end{array}$ & $\begin{array}{l}-0.000 \\
(0.004)\end{array}$ & $\begin{array}{l}-0.014 \\
(0.028)\end{array}$ \\
\hline $\begin{array}{l}\text { Observations } \\
\text { R-squared }\end{array}$ & $\begin{array}{c}354,296 \\
0.255\end{array}$ & $\begin{array}{c}355,610 \\
0.022 \\
\end{array}$ & $\begin{array}{c}351,700 \\
0.005\end{array}$ & $\begin{array}{c}357,134 \\
0.032 \\
\end{array}$ & $\begin{array}{c}23,576 \\
0.070 \\
\end{array}$ \\
\hline
\end{tabular}

Notes: all estimates control for age and its square, gender and educational level. Region and year fixed effects and region-specific trends are also included. Robust standard errors are in parentheses, clustered at the year-region level. $* * * \mathrm{p}<0.01, * * \mathrm{p}<0.05, * \mathrm{p}<0.1$

Table 5 - Objective health status

\begin{tabular}{|c|c|c|c|c|c|c|}
\hline & (1) & $\begin{array}{c}(2) \\
\text { Emergency } \\
\text { Room } \\
\text { access }\end{array}$ & $\begin{array}{c}\text { (3) } \\
\text { Day } \\
\text { Hospital } \\
\text { access }\end{array}$ & Hospitalization & $\begin{array}{c}(5) \\
\text { Average } \\
\text { Life } \\
\text { Expectancy }\end{array}$ & $\begin{array}{c}\text { (6) } \\
\text { Infant } \\
\text { Mortality } \\
\text { Rate }\end{array}$ \\
\hline & \multicolumn{6}{|c|}{ Panel A: 1993-2007 } \\
\hline Reform & $\begin{array}{l}-0.001 \\
(0.005)\end{array}$ & $\begin{array}{c}-0.015 * * \\
(0.006)\end{array}$ & & $\begin{array}{c}-0.001 \\
(0.003)\end{array}$ & $\begin{array}{l}0.105^{*} \\
(0.055)\end{array}$ & $\begin{array}{c}1.700 \\
(2.312)\end{array}$ \\
\hline Observations & 266 & 266 & & 266 & 266 & 266 \\
\hline \multirow[t]{2}{*}{ R-squared } & 0.735 & 0.859 & & 0.950 & 0.991 & 0.824 \\
\hline & \multicolumn{6}{|c|}{ Panel C: 1993-1999 } \\
\hline Reform & $\begin{array}{c}0.008 \\
(0.005)\end{array}$ & $\begin{array}{c}-0.03 * * * \\
(0.006)\end{array}$ & $\begin{array}{c}-0.004 * * \\
(0.002)\end{array}$ & $\begin{array}{r}-0.006 * \\
(0.003)\end{array}$ & $\begin{array}{c}0.073 \\
(0.055)\end{array}$ & $\begin{array}{c}1.451 \\
(2.429)\end{array}$ \\
\hline Observations & 133 & 133 & 133 & 133 & 133 & 133 \\
\hline R-squared & 0.791 & 0.915 & 0.607 & 0.954 & 0.980 & 0.859 \\
\hline
\end{tabular}

Notes: all estimates control for region and year fixed effects. Robust standard errors are in parentheses, clustered at the region-treatment level. $* * * \mathrm{p}<0.01, * * \mathrm{p}<0.05, * \mathrm{p}<0.1$ 
Table 6 - Private health insurance ownership

\begin{tabular}{|c|c|c|c|c|}
\hline & $(1)$ & $(2)$ & (3) & $(4)$ \\
\hline & \multicolumn{4}{|c|}{ Health insurance ownership by at least one family member } \\
\hline & \multicolumn{2}{|c|}{$1993-2007$} & \multicolumn{2}{|c|}{ 1993-1999 } \\
\hline \multirow[t]{2}{*}{ Reform } & $0.008^{*}$ & 0.003 & 0.010 & -0.019 \\
\hline & $(0.005)$ & $(0.006)$ & $(0.007)$ & $(0.011)$ \\
\hline Region FE * trend & No & Yes & no & yes \\
\hline Observations & 293,598 & 293,598 & 153,587 & 153,587 \\
\hline R-squared & 0.123 & 0.123 & 0.120 & 0.120 \\
\hline
\end{tabular}

Notes: all estimates control for age and its square, gender and educational level as averages at the family level. Region and year fixed effects are also included. Columns (2) and (4) also controls for region specific trends. Robust standard errors are in parentheses, clustered at the year-region level. $* * * \mathrm{p}<0.01,{ }^{* *} \mathrm{p}<0.05,{ }^{*} \mathrm{p}<0.1$

Table 7 - A cohort analysis

(1)

(2)

(3)

(4)

(5)

SAH $\begin{gathered}\text { Emergency } \\
\text { Room access }\end{gathered} \quad \begin{gathered}\text { Day Hospital } \\
\text { access }\end{gathered}$ Hospitalization \begin{tabular}{c}
$\begin{array}{c}\text { Satisfaction with } \\
\text { the service if } \\
\text { hospitalized }\end{array}$ \\
\hline
\end{tabular}

\begin{tabular}{|c|c|c|c|c|c|}
\hline \multirow{3}{*}{ treatment } & \multicolumn{5}{|c|}{ Panel A: 1993-2007 } \\
\hline & $-0.008 * *$ & $-0.017 * * *$ & & $0.003 *$ & $-0.043 * * *$ \\
\hline & $(0.003)$ & $(0.003)$ & & $(0.002)$ & $(0.016)$ \\
\hline \multirow[t]{2}{*}{ treatment*before 48} & $0.015 * * *$ & 0.001 & & $-0.017 * * *$ & $0.031 *$ \\
\hline & $(0.005)$ & $(0.002)$ & & $(0.002)$ & $(0.018)$ \\
\hline Observations & 660,326 & 663,894 & & 665,660 & 34,726 \\
\hline \multirow[t]{2}{*}{ R-squared } & 0.253 & 0.016 & & 0.030 & 0.066 \\
\hline & \multicolumn{5}{|c|}{ Panel B: 1993-1999 } \\
\hline \multirow[t]{2}{*}{ treatment } & -0.003 & $-0.028 * * *$ & $-0.003 *$ & 0.000 & $-0.073 * * *$ \\
\hline & $(0.005)$ & $(0.004)$ & $(0.002)$ & $(0.002)$ & $(0.026)$ \\
\hline \multirow[t]{2}{*}{ treatment*before 48} & $0.029 * * *$ & -0.004 & 0.000 & $-0.020 * * *$ & $0.067 * * *$ \\
\hline & $(0.006)$ & $(0.003)$ & $(0.002)$ & $(0.003)$ & $(0.023)$ \\
\hline Observations & 354,296 & 355,610 & 351,700 & 357,134 & 23,576 \\
\hline R-squared & 0.255 & 0.021 & 0.005 & 0.032 & 0.069 \\
\hline
\end{tabular}

Notes: all estimates control for age and its square, gender and educational level. Region and year fixed effects are also included. Before 48 is a dummy variable for those born before 1948. Robust standard errors are in parentheses, clustered at the year-region level. $* * * \mathrm{p}<0.01, * * \mathrm{p}<0.05, * \mathrm{p}<0.1$ 
Table 8 - Heterogeneous effects of the reform, by age.

\begin{tabular}{|c|c|c|c|c|c|c|c|c|c|}
\hline & \multirow[t]{2}{*}{ (1) } & \multirow{2}{*}{\multicolumn{3}{|c|}{$\begin{array}{l}(2) \quad(3) \\
\text { Time period: } 1993-2007\end{array}$}} & \multirow[t]{2}{*}{ (5) } & \multicolumn{2}{|c|}{ (6) } & \multicolumn{2}{|c|}{$(8) \quad(9)$} \\
\hline & & & & & & \multirow[b]{2}{*}{$\begin{array}{c}\text { Emergency } \\
\text { Room } \\
\text { access }\end{array}$} & \multirow[b]{2}{*}{$\begin{array}{c}\text { Day } \\
\text { Hospital } \\
\text { access }\end{array}$} & \multirow[b]{2}{*}{ Hospitaliz. } & \multirow[b]{2}{*}{$\begin{array}{c}\text { Satisfaction } \\
\text { with the } \\
\text { service if } \\
\text { hospitalized }\end{array}$} \\
\hline & SAH & $\begin{array}{c}\text { Emergency } \\
\text { Room } \\
\text { access }\end{array}$ & Hospitaliz. & $\begin{array}{l}\text { Satisfaction } \\
\text { with the } \\
\text { service if } \\
\text { hospitalized }\end{array}$ & SAH & & & & \\
\hline treatment & $\begin{array}{c}\text { age }<25 \\
0.000 \\
(0.004)\end{array}$ & $\begin{array}{c}-0.031^{* * *} \\
(0.005)\end{array}$ & $\begin{array}{l}-0.003 \\
(0.002)\end{array}$ & $\begin{array}{l}-0.055 \\
(0.037)\end{array}$ & $\begin{array}{c}0.008 \\
(0.005)\end{array}$ & $\begin{array}{c}-0.049 * * * \\
(0.006)\end{array}$ & $\begin{array}{l}-0.004 \\
(0.003)\end{array}$ & $\begin{array}{l}-0.003 \\
(0.003)\end{array}$ & $\begin{array}{l}-0.009 \\
(0.056)\end{array}$ \\
\hline $\begin{array}{l}\text { Observations } \\
\text { R-squared }\end{array}$ & $\begin{array}{c}89,050 \\
0.015\end{array}$ & $\begin{array}{c}89,534 \\
0.027 \\
\end{array}$ & $\begin{array}{c}89,741 \\
0.016 \\
\end{array}$ & & $\begin{array}{c}52,671 \\
0.017 \\
\end{array}$ & $\begin{array}{c}52,905 \\
0.032 \\
\end{array}$ & $\begin{array}{c}52,299 \\
0.003 \\
\end{array}$ & $\begin{array}{c}53,125 \\
0.014 \\
\end{array}$ & $\begin{array}{l}2,059 \\
0.065\end{array}$ \\
\hline treatment & $\begin{array}{c}\text { age } 25-6 \\
-0.002 \\
(0.003)\end{array}$ & $\begin{array}{c}4 \\
-0.016^{* * * *} \\
\quad(0.003)\end{array}$ & $\begin{array}{l}-0.001 \\
(0.002)\end{array}$ & $\begin{array}{l}-0.008 \\
(0.016)\end{array}$ & $\begin{array}{c}0.011^{* *} \\
(0.005)\end{array}$ & $\begin{array}{c}-0.030 * * * \\
(0.004)\end{array}$ & $\begin{array}{c}-0.003 * * \\
(0.002)\end{array}$ & $\begin{array}{c}-0.008 * * * \\
(0.002)\end{array}$ & $\begin{array}{l}-0.050^{*} \\
(0.026)\end{array}$ \\
\hline $\begin{array}{l}\text { Observations } \\
\text { R-squared }\end{array}$ & $\begin{array}{c}439,739 \\
0.102\end{array}$ & $\begin{array}{c}442,133 \\
0.015\end{array}$ & $\begin{array}{c}443,150 \\
0.018\end{array}$ & $\begin{array}{c}19,154 \\
0.061\end{array}$ & $\begin{array}{c}237,300 \\
0.110\end{array}$ & $\begin{array}{c}238,211 \\
0.021\end{array}$ & $\begin{array}{c}235,717 \\
0.004\end{array}$ & $\begin{array}{c}239,145 \\
0.018\end{array}$ & $\begin{array}{c}13,514 \\
0.060\end{array}$ \\
\hline treatment & $\begin{array}{c}\text { age }>64 \\
-0.007 \\
(0.007)\end{array}$ & $\begin{array}{c}-0.009 * * \\
(0.004)\end{array}$ & $\begin{array}{l}-0.006 \\
(0.004)\end{array}$ & $\begin{array}{c}-0.047 * * \\
(0.018)\end{array}$ & $\begin{array}{c}0.004 \\
(0.008)\end{array}$ & $\begin{array}{l}-0.013^{*} \\
(0.007)\end{array}$ & $\begin{array}{l}-0.002 \\
(0.004)\end{array}$ & $\begin{array}{l}-0.009 \\
(0.006)\end{array}$ & $\begin{array}{l}-0.025 \\
(0.027)\end{array}$ \\
\hline $\begin{array}{l}\text { Observations } \\
\text { R-squared }\end{array}$ & $\begin{array}{c}131,537 \\
0.067 \\
\end{array}$ & $\begin{array}{c}132,227 \\
0.012 \\
\end{array}$ & $\begin{array}{c}132,769 \\
0.030 \\
\end{array}$ & $\begin{array}{c}12,927 \\
0.084 \\
\end{array}$ & $\begin{array}{c}64,325 \\
0.061 \\
\end{array}$ & $\begin{array}{c}64,494 \\
0.017 \\
\end{array}$ & $\begin{array}{c}63,684 \\
0.003 \\
\end{array}$ & $\begin{array}{c}64,864 \\
0.032 \\
\end{array}$ & $\begin{array}{l}8,003 \\
0.098 \\
\end{array}$ \\
\hline treatment & $\begin{array}{c}\text { age } 25-44 \\
-0.001 \\
(0.003)\end{array}$ & $\begin{array}{c}4 \\
-0.018 * * * \\
(0.004)\end{array}$ & $\begin{array}{l}-0.002 \\
(0.002)\end{array}$ & $\begin{array}{c}0.003 \\
(0.023)\end{array}$ & $\begin{array}{l}0.009^{*} \\
(0.005)\end{array}$ & $\begin{array}{c}-0.035^{* * * *} \\
(0.005)\end{array}$ & $\begin{array}{l}-0.003 \\
(0.002)\end{array}$ & $\begin{array}{c}-0.006^{* *} \\
(0.003)\end{array}$ & $\begin{array}{l}-0.032 \\
(0.032)\end{array}$ \\
\hline $\begin{array}{l}\text { Observations } \\
\text { R-squared }\end{array}$ & $\begin{array}{c}236,874 \\
0.028 \\
\end{array}$ & $\begin{array}{c}238,212 \\
0.018 \\
\end{array}$ & $\begin{array}{c}238,695 \\
0.019 \\
\end{array}$ & $\begin{array}{l}9,166 \\
0.058 \\
\end{array}$ & $\begin{array}{c}129,435 \\
0.031 \\
\end{array}$ & $\begin{array}{c}130,005 \\
0.024 \\
\end{array}$ & $\begin{array}{c}128,542 \\
0.003 \\
\end{array}$ & $\begin{array}{c}130,482 \\
0.020 \\
\end{array}$ & $\begin{array}{l}6,515 \\
0.058 \\
\end{array}$ \\
\hline treatment & $\begin{array}{l}\text { age 45-64 } \\
-0.004 \\
(0.005)\end{array}$ & $\begin{array}{c}4.013^{* * *} \\
(0.003)\end{array}$ & $\begin{array}{l}-0.001 \\
(0.002)\end{array}$ & $\begin{array}{l}-0.021 \\
(0.020)\end{array}$ & $\begin{array}{c}0.011 \\
(0.007)\end{array}$ & $\begin{array}{c}-0.026^{* * * *} \\
(0.005)\end{array}$ & $\begin{array}{l}-0.004 * \\
(0.002)\end{array}$ & $\begin{array}{c}-0.010^{* * *} \\
(0.003)\end{array}$ & $\begin{array}{c}-0.073 * * \\
(0.032)\end{array}$ \\
\hline $\begin{array}{l}\text { Observations } \\
\text { R-squared }\end{array}$ & $\begin{array}{c}202,865 \\
0.055\end{array}$ & $\begin{array}{c}203,921 \\
0.013\end{array}$ & $\begin{array}{c}204,455 \\
0.020\end{array}$ & $\begin{array}{l}9,988 \\
0.075\end{array}$ & $\begin{array}{c}107,865 \\
0.057\end{array}$ & $\begin{array}{c}108,206 \\
0.017\end{array}$ & $\begin{array}{c}107,175 \\
0.002\end{array}$ & $\begin{array}{c}108,663 \\
0.019\end{array}$ & $\begin{array}{l}6,999 \\
0.073\end{array}$ \\
\hline
\end{tabular}

Notes: all estimates control for age and its square, gender and educational level. Region and year fixed effects are also included. Robust standard errors are in parentheses, clustered at the year-region level. *** $\mathrm{p}<0.01,{ }^{* *} \mathrm{p}<0.05,{ }^{*} \mathrm{p}<0.1$ 
Table 9 - Heterogeneous effects of the reform, by gender.

\begin{tabular}{|c|c|c|c|c|c|c|c|c|c|}
\hline & (1) & & (3) & (4) & (5) & $(6)$ & $(7)$ & (8) & (9) \\
\hline & \multicolumn{4}{|c|}{ Time period: $1993-2007$} & \multicolumn{5}{|c|}{ Time period: $1993-1999$} \\
\hline & $\mathrm{SAH}$ & $\begin{array}{c}\text { Emergency } \\
\text { Room } \\
\text { access }\end{array}$ & Hospitaliz. & $\begin{array}{c}\text { Satisfaction } \\
\text { with the } \\
\text { service if } \\
\text { hospitalized }\end{array}$ & $\mathrm{SAH}$ & $\begin{array}{c}\text { Emergency } \\
\text { Room } \\
\text { access }\end{array}$ & $\begin{array}{c}\text { Day } \\
\text { Hospital } \\
\text { access }\end{array}$ & Hospitaliz. & $\begin{array}{c}\text { Satisfaction } \\
\text { with the } \\
\text { service if } \\
\text { hospitalized }\end{array}$ \\
\hline $\begin{array}{l}\text { Males } \\
\text { treatment }\end{array}$ & $\begin{array}{l}-0.006 * \\
(0.003)\end{array}$ & $\begin{array}{c}-0.020 * * * \\
(0.004)\end{array}$ & $\begin{array}{l}-0.004 * \\
(0.002)\end{array}$ & $\begin{array}{c}-0.038 * * \\
(0.015)\end{array}$ & $\begin{array}{c}0.006 \\
(0.005)\end{array}$ & $\begin{array}{c}-0.035^{* * *} \\
(0.006)\end{array}$ & $\begin{array}{l}-0.002 \\
(0.002)\end{array}$ & $\begin{array}{c}-0.010 * * * \\
(0.003)\end{array}$ & $\begin{array}{c}-0.059 * * \\
(0.024)\end{array}$ \\
\hline $\begin{array}{l}\text { Obs. } \\
\text { R- } \\
\text { squared }\end{array}$ & 317,688 & 319,201 & 320,023 & 15,909 & 170,842 & 171,375 & 169,348 & 172,083 & 10,826 \\
\hline $\begin{array}{l}\text { Females } \\
\text { treatment }\end{array}$ & $\begin{array}{c}0.001 \\
(0.004)\end{array}$ & $\begin{array}{c}-0.014 * * * \\
(0.003)\end{array}$ & $\begin{array}{c}-0.002 \\
(0.002)\end{array}$ & $\begin{array}{c}-0.014 \\
(0.014)\end{array}$ & $\begin{array}{c}0.013 * * * \\
(0.005)\end{array}$ & $\begin{array}{c}-0.025^{* * *} \\
(0.004)\end{array}$ & $\begin{array}{c}-0.005^{* *} \\
(0.002)\end{array}$ & $\begin{array}{c}-0.007 * * \\
(0.003)\end{array}$ & $\begin{array}{l}-0.006 \\
(0.024)\end{array}$ \\
\hline $\begin{array}{l}\text { Obs. } \\
\text { R- } \\
\text { squared }\end{array}$ & 342,638 & 344,693 & 345,637 & 18,817 & 183,454 & 184,235 & 182,352 & 185,051 & 12,750 \\
\hline
\end{tabular}

Notes: all estimates control for age and its square and educational level. Region and year fixed effects are also included.

Robust standard errors are in parentheses, clustered at the year-region level. *** $\mathrm{p}<0.01, * * \mathrm{p}<0.05, * \mathrm{p}<0.1$ 
Table 10 - Heterogeneous effects of the reform, by educational level

(1)

(2)
(4)

1993-2007

SAH $\begin{gathered}\text { Emergency } \\ \text { Room } \\ \text { access }\end{gathered}$ Hospitaliz. $\begin{gathered}\begin{array}{c}\text { Satisfaction } \\ \text { with the } \\ \text { service if } \\ \text { hospitalized }\end{array} \\ \end{gathered}$

(5)

(6)

6)

(7)

1993-1999

(8)

(9)

$\begin{array}{cccc}\text { SAH } & \begin{array}{c}\text { Emergency } \\ \text { Room }\end{array} & \begin{array}{c}\text { Day } \\ \text { Hospital } \\ \text { access }\end{array} & \text { Hospitaliz. }\end{array}$

Satisfaction

with the

service if

hospitalized

Compulsory education

\begin{tabular}{|c|c|c|c|c|c|c|c|c|c|}
\hline treatment & $\begin{array}{c}-0.004 \\
(0.004)\end{array}$ & $\begin{array}{c}-0.014 * * * \\
(0.003)\end{array}$ & $\begin{array}{c}-0.003 \\
(0.002)\end{array}$ & $\begin{array}{c}-0.026 * * \\
(0.013)\end{array}$ & $\begin{array}{c}0.008 \\
(0.005)\end{array}$ & $\begin{array}{c}-0.025 * * * \\
(0.005)\end{array}$ & $\begin{array}{l}-0.002 \\
(0.002)\end{array}$ & $\begin{array}{c}-0.009 * * * \\
(0.003)\end{array}$ & $\begin{array}{c}-0.032 * \\
(0.017)\end{array}$ \\
\hline Obs. & 405,330 & 407,553 & 408,822 & 25,515 & 223,607 & 224,475 & 221,757 & 225,516 & 17,407 \\
\hline R-sq. & 0.244 & 0.015 & 0.031 & 0.065 & 0.244 & 0.020 & 0.004 & 0.032 & 0.067 \\
\hline \multicolumn{10}{|c|}{ Upper secondary education } \\
\hline treatment & $\begin{array}{c}0.001 \\
(0.004)\end{array}$ & $\begin{array}{c}-0.021 * * * \\
(0.004)\end{array}$ & $\begin{array}{c}-0.004 * * \\
(0.002)\end{array}$ & $\begin{array}{c}-0.034 \\
(0.023)\end{array}$ & $\begin{array}{l}0.01 * * \\
(0.004)\end{array}$ & $\begin{array}{c}-0.037 * * * \\
(0.005)\end{array}$ & $\begin{array}{c}-0.01 * * \\
(0.002)\end{array}$ & $\begin{array}{c}-0.008 * * * \\
(0.003)\end{array}$ & $\begin{array}{c}-0.037 \\
(0.041)\end{array}$ \\
\hline Obs. & 206,355 & 207,374 & 207,796 & 7,529 & 107,591 & 107,953 & 106,961 & 108,355 & 5,075 \\
\hline R-sq. & 0.117 & 0.015 & 0.017 & 0.056 & 0.117 & 0.022 & 0.005 & 0.018 & 0.060 \\
\hline \multicolumn{10}{|c|}{ Tertiary education } \\
\hline treatment & $\begin{array}{c}-0.001 \\
(0.008)\end{array}$ & $\begin{array}{c}-0.018 * * * \\
(0.005)\end{array}$ & $\begin{array}{c}-0.003 \\
(0.003)\end{array}$ & $\begin{array}{c}0.002 \\
(0.046)\end{array}$ & $\begin{array}{c}0.03 * * * \\
(0.012)\end{array}$ & $\begin{array}{c}-0.040 * * * \\
(0.009)\end{array}$ & $\begin{array}{c}-0.01 * * \\
(0.006)\end{array}$ & $\begin{array}{l}-0.007 \\
(0.005)\end{array}$ & $\begin{array}{c}0.023 \\
(0.088)\end{array}$ \\
\hline Obs. & 48,641 & 48,967 & 49,042 & 1,682 & 23,098 & 23,182 & 22,982 & 23,263 & 1,094 \\
\hline R-sq. & 0.107 & 0.012 & 0.022 & 0.091 & 0.109 & 0.016 & 0.009 & 0.024 & 0.111 \\
\hline
\end{tabular}

Notes: all estimates control for age and its square and gender. Region and year fixed effects are also included. Robust standard errors are in parentheses, clustered at the year-region level. *** $\mathrm{p}<0.01, * * \mathrm{p}<0.05, * \mathrm{p}<0.1$ 
Table 11 - Heterogeneity by region

\begin{tabular}{|c|c|c|c|c|}
\hline & (1) & (2) & (3) & (4) \\
\hline & $\mathrm{SAH}$ & $\begin{array}{l}\text { Emergency } \\
\text { Room access }\end{array}$ & $\begin{array}{l}\text { Day Hospital } \\
\text { access }\end{array}$ & Hospitalization \\
\hline & \multicolumn{4}{|c|}{ Panel A: 1993-2007 } \\
\hline \multirow[t]{2}{*}{ Piedmont*treatment } & 0.003 & -0.006 & & 0.002 \\
\hline & $(0.004)$ & $(0.004)$ & & $(0.002)$ \\
\hline \multirow[t]{2}{*}{ Lombardy*treatment } & $0.011 * * *$ & $-0.033 * * *$ & & $-0.011 * * *$ \\
\hline & $(0.004)$ & $(0.003)$ & & $(0.003)$ \\
\hline \multirow[t]{2}{*}{ Veneto*treatment } & $-0.011 *$ & $-0.035 * * *$ & & $-0.005 * *$ \\
\hline & $(0.006)$ & $(0.009)$ & & $(0.003)$ \\
\hline \multirow[t]{2}{*}{ EmiliaRomagna*treatment } & -0.001 & $-0.035 * * *$ & & $-0.009 * *$ \\
\hline & $(0.006)$ & $(0.005)$ & & $(0.004)$ \\
\hline \multirow[t]{2}{*}{ Tuscany*treatment } & 0.010 & $-0.022 * * *$ & & $-0.011 * * *$ \\
\hline & $(0.006)$ & $(0.004)$ & & $(0.003)$ \\
\hline \multirow[t]{2}{*}{ Umbria*treatment } & $0.025 * *$ & $-0.019 * * *$ & & $-0.007 * *$ \\
\hline & $(0.011)$ & $(0.005)$ & & $(0.003)$ \\
\hline \multirow[t]{2}{*}{ Lazio*treatment } & $-0.020 * *$ & 0.003 & & 0.002 \\
\hline & $(0.009)$ & $(0.007)$ & & $(0.001)$ \\
\hline \multirow[t]{2}{*}{ Sicily*treatment } & $-0.016 * * *$ & $0.010 * * *$ & & $0.009 * * *$ \\
\hline & $(0.005)$ & $(0.003)$ & & $(0.003)$ \\
\hline Observations & 660,326 & 663,894 & & 665,660 \\
\hline \multirow[t]{2}{*}{ R-squared } & 0.253 & 0.017 & & 0.030 \\
\hline & \multicolumn{4}{|c|}{ Panel B: 1993-1999 } \\
\hline \multirow[t]{2}{*}{ Lombardy*treatment } & $0.015 * * *$ & $-0.033 * * *$ & -0.001 & $-0.009 * * *$ \\
\hline & $(0.003)$ & $(0.005)$ & $(0.002)$ & $(0.003)$ \\
\hline \multirow[t]{2}{*}{ Veneto*treatment } & 0.003 & $-0.028 * * *$ & -0.004 & -0.003 \\
\hline & $(0.004)$ & $(0.010)$ & $(0.003)$ & $(0.004)$ \\
\hline \multirow[t]{2}{*}{ EmiliaRomagna*treatment } & 0.000 & $-0.035 * * *$ & $-0.010 * * *$ & $-0.010 * * *$ \\
\hline & $(0.011)$ & $(0.005)$ & $(0.003)$ & $(0.004)$ \\
\hline \multirow[t]{2}{*}{ Tuscany*treatment } & $0.012 *$ & $-0.020 * * *$ & 0.001 & $-0.011 * * *$ \\
\hline & $(0.007)$ & $(0.005)$ & $(0.002)$ & $(0.003)$ \\
\hline \multirow[t]{2}{*}{ Umbria*treatment } & $0.026 *$ & $-0.024 * * *$ & $-0.007 * *$ & $-0.007 *$ \\
\hline & $(0.015)$ & $(0.005)$ & $(0.003)$ & $(0.004)$ \\
\hline Observations & 354,296 & 355,610 & 351,700 & 357,134 \\
\hline R-squared & 0.255 & 0.021 & 0.005 & 0.031 \\
\hline
\end{tabular}

Notes: all estimates control for age and its square and gender. Region and year fixed effects are also included. Robust standard errors are in parentheses, clustered at the year-region level. *** $\mathrm{p}<0.01, * * \mathrm{p}<0.05, * \mathrm{p}<0.1$ 
Figure 1 - Self assessed health and health service use by treatment status

a) Self assessed health

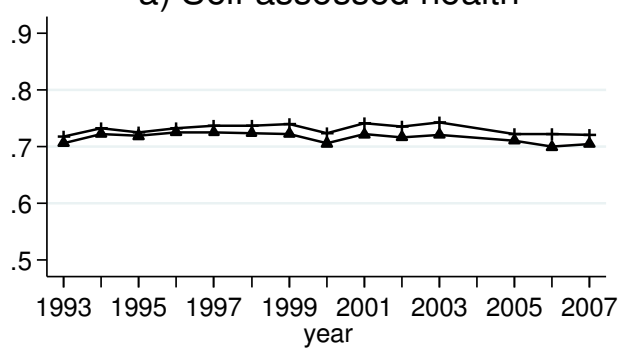

c) Hospitalization

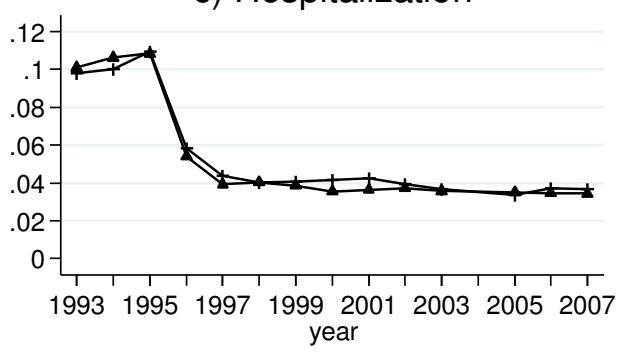

b) Emergency room

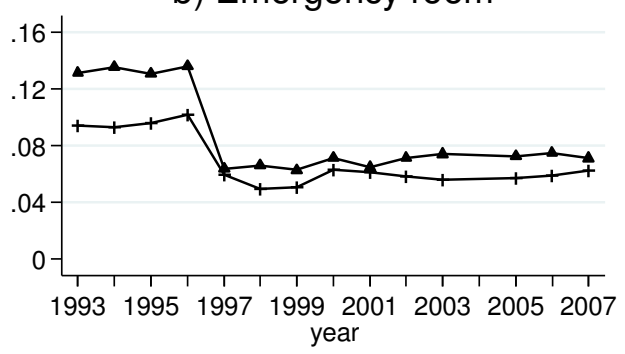

d) Day hospital

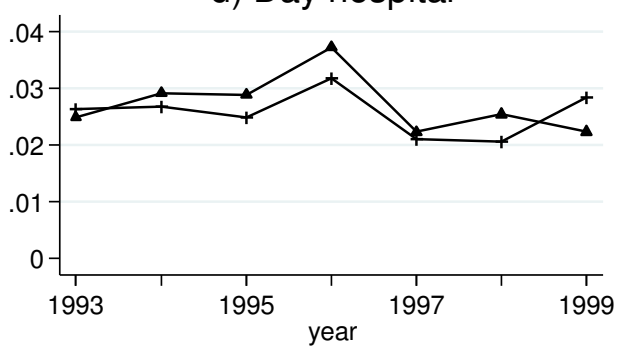

